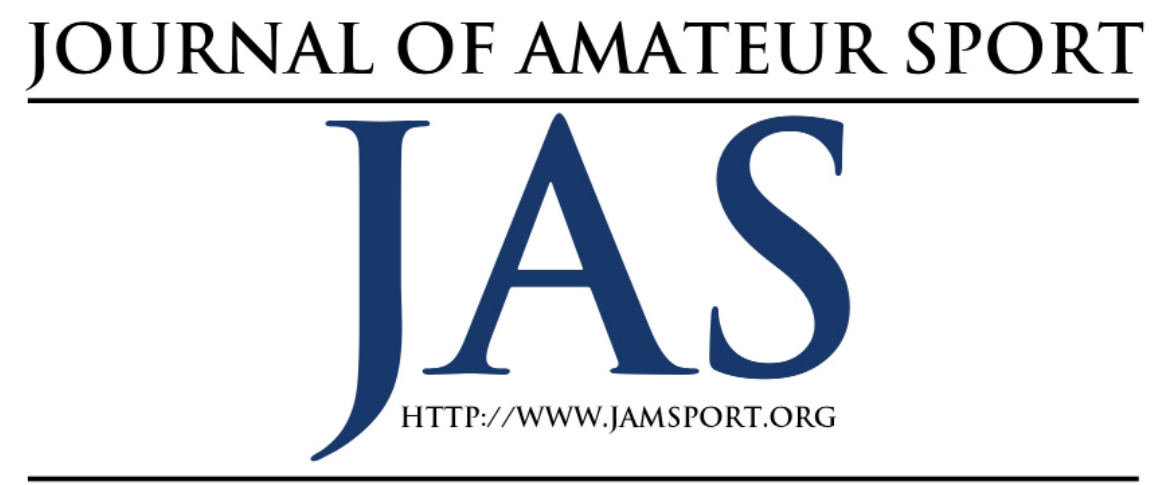

\title{
Education Versus Athletics: What Will Division I Football and Basketball Players Choose?
}

\author{
Andy Rudd ${ }^{1} \quad$ B. David Ridpath ${ }^{2}$ \\ ${ }^{1}$ Belmont Abbey College \\ ${ }^{2}$ Ohio University
}

For many years the desire for money and winning in Division I athletics, particularly in the sports of football (Football Bowl Subdivision) and men's basketball, have encouraged colleges and universities to provide special admission for athletes with exceptional athletic ability, who in turn, often are less prepared to succeed academically. This has resulted in the widespread occurrence of unethical academic support practices (e.g., taking classes and writing papers for students and providing answers to exams) in order to maintain athletes' eligibility and increase graduation rates to appease the public and to present the case that intercollegiate athletics are about education first. As one means of curbing academic misconduct, the authors recommend providing Division I football and basketball the option of playing their sport only without any academic eligibility requirement. Athletes who are struggling academically or lack academic commitment would no longer need to be bolstered by illegitimate academic support or less than accurate metrics. The present exploratory study sought to determine how many Division I football and basketball players would choose the option of playing their sport only versus playing and pursuing their degree under current National Collegiate Athletic Association Guidelines (NCAA) guidelines. The results showed that the majority would still choose to play and pursue their degree. Overall, the belief that one can play professionally did not diminish athletes' desire to play and earn their degree. However, there were also a percentage of athletes that believed they can play professionally and also desired to play their sport only. 
$\mathrm{C}$ ommercialization has proven to play a powerful role in Division examples include the Division I men's basketball national championship tournament and the College Football Playoff. The basketball tournament generates an average of $\$ 771$ million annually in National Collegiate Athletic Association (NCAA) media rights fees over a 14-year period (Edelman, 2017; Gurney, Lopiano, \& Zimbalist, 2017). A percentage of this money is allocated to the conferences based on how far their respective teams advance in the tournament. The conferences then distribute money to the individual teams / universities at their discretion (Edelman, 2017; Gurney et al., 2017). For the football playoff, ESPN pays the Football Bowl Subdivision (FBS) conferences $\$ 600$ million per year to televise the College Football Playoff (Smith, 2017). Akin to the NCAA Division I men's basketball tournament, the revenue is not shared equally across the 10 FBS conferences and four independents. Rather, $75 \%$ percent of the money is distributed across the Power Five conference members (Atlantic Coast Conference, Big Ten Conference, Big 12 Conference, Pacific - 12 Conference, and Southeastern Conference) while the remaining $25 \%$ is given to the other five FBS conferences and its 60 members (Gurney et al., 2017).

It is clear that there is not only an immense amount of money involved in commercialized college athletics, but that there is also more money for those at the top. Thus, according to Lumpkin, Stoll, and Beller (2003), many university administrators adhere to the cycle of winning $=$ fans $=$ money $=$ winning $=$ fans $=$ money. In essence, many college athletic administrators believe that more spending can mean more wins and revenue, thus leading to other potential intangible benefits, and the cycle continues (Gurney et al., 2017). However, doing so has resulted in universities continuing to engage in unethical recruiting practices in order to garner marquee players that will contribute to the formula of winning and revenue generation (Gurney et al., 2017; Nixon, 2014; Simon, Torres, \& Hager, 2015).

Perhaps the most pervasive recruiting problem currently plaguing Division I college athletics is concerning academic fraud (Gurney et al., 2017; Nixon, 2014). In an effort to provide football and basketball coaches the players of their choice, many universities and colleges relax their admission standards to the point of admitting student-athletes that are not prepared to do college-level work (Gurney et al., 2017; Nixon 2014; Ridpath, Kiger, Eagle \& Mak, 2007; Simon et al., 2015). Specifically, Barker (2014), a reporter for the Baltimore Sun investigated a number of universities from the Atlantic Coast Conference and Big-Ten conference that provide special admissions to athletes primarily in football and basketball. Barker (2014) found that many of these special admits 
do not graduate or do as well in the classroom compared to regular admits.

The practice of providing special admissions has spawned numerous cases of unethical academic support to academically unqualified studentathletes, particularly football and basketball players (Gurney et al., 2017; Ridpath, 2010; Wolverton, 2014). In 2015, there were 20 (18 Division I schools) universities or colleges under investigation for academic fraud in college athletics (Axe, 2015). One of the most egregious examples occurred at the University of North Carolina at Chapel Hill involving 18 years of academic misconduct in the form of studentathletes receiving grades for courses in name only and tutors writing papers for athletes (Smith \& Willingham, 2015). There was also the work of a former college tutor and assistant basketball coach who cheated for hundreds of athletes by providing papers, answers to exams, and completing online courses to help athletes meet NCAA eligibility requirements (Wolverton, 2014). Other cases have included the suspension of 23 Florida State University football players for cheating in a music course, Georgia Southern University Assistant Director of Student Services doing extra credit work for football players, and Syracuse University's athletic staff providing inappropriate assistance on papers to three football players and a star basketball player (James, 2016; O’Brien, 2015; Zinser, 2009).
As a means of curtailing the practice of using fraudulent academic support practices, the authors suggest allowing Division I basketball and football players the freedom to choose the pursuit of a college degree or not while participating in athletics. It is proposed that doing so would remedy the problem of academically unqualified student- athletes attempting to earn degrees that they are wholly unprepared to achieve. However, it is currently unknown how many student-athletes would choose solely to participate in athletics. As a result, the purpose of this study was to conduct an exploratory investigation into Division I basketball and football players' attitudes towards the option of participating in college athletics without pursuing a degree. Accordingly, the research question this study sought to answer was the following: What percentage of Division I basketball and football players would choose to participate in college athletics without pursuing a degree versus the percentage that would choose to do both and why?

In the following section we examine past and current ideas for reforming commercialized college athletics and its impact on academic misconduct and consider their potential shortcomings or failures. We then offer our solution for alleviating the practice of academic misconduct in college athletics. 


\section{Reform in College Athletics Academic Standards}

In 2003, former NCAA President Myles Brand raised the academic standards for athletics participation as part of his Academic Performance Program (Gurney et al., 2017). To be initially eligible students are currently required to obtain a 2.3 over 16 high school core courses along with a combined minimum SAT score of 900 on a sliding scale (Gurney et al., 2017; Oriard, 2012). The use of a sliding scale allows students with a higher GPA to earn a lower standardized test score. For example, a student earning a 3.55 GPA could receive an SAT of 400 (the score for getting no correct answers) and be athletically eligible (NCAA, 2017-18).

Teams must also meet what is called the Academic Progress Rate (APR). The APR is a numeric score given to each collegiate team based on the number of players that have remained in school and are academically eligible to compete (NCAA, 2017-18). Teams are required to achieve a minimum score of 930 (which is associated with approximately half of a team graduating) in order to be eligible for postseason competition. A threelevel penalty system is imposed for each consecutive year that a team fails to meet the 930 standard (Gurney et al., 2017; NCAA 2017-18).

Gurney et al. (2015) and Gurney et al. (2017) assert that the current eligibility standards allow for too many underprepared and academically unqualified athletes to be eligible for athletics. This results in the practice of academic misconduct in order to keep athletes athletically eligible. As a result, Gurney et al. (2015) and Gurney et al. (2017) have proposed a set of higher standards for both initial and ongoing eligibility. First, Gurney et al. (2015) recommends the NCAA require a minimum anchored SAT score of 820 (combined math and verbal) or a composite ACT score of 17. Second, college athletes should more closely match the academic profile of the nonathletes at a given institution. Studentathletes whose academic profile (GPA and standardized test score) are one standard deviation below the mean academic profile of the incoming freshmen class should be ineligible to participate in athletics their freshman year. Third, student-athletes must maintain a minimum of a $2.0 \mathrm{GPA}$ (the NCAA requires a 1.8 GPA and 1.9 GPA for sophomores and juniors respectively) for continued athletics participation as well as sufficient progress towards degree completion, (e.g., 50\% of degree completion beginning junior year) (Gurney et al. 2017). Fourth, the APR metric used to hold teams accountable for maintaining a student's eligibility and progress towards graduation should be eradicated because many higher-powered universities have the ability to manipulate the required APR score of 930.

Lumpkin et al. (2012) have also recommended changes to the current academic standards in intercollegiate athletics. Rather than proposing specific 
increases to the current NCAA eligibility standards, they suggest abolishing the practice of special admissions while requiring that athletes meet the same admission standards as non athletes. Lumpkin et al. (2012) also suggest reinstituting the rule of not allowing freshmen to participate in any form of college athletics their first year. In theory, this would allow freshmen time to mature and adjust to college life. Lastly, they recommend that coaches should have a contractual obligation to graduate their players within five years or face termination.

It is important to note that throughout the history of college athletics there have been numerous attempts at increasing academic standards (Gurney et al., 2017; Oriard, 2012). But, in many cases the increased standards have been contested and then lowered. For example, in 1962 the NCAA adopted the 1.6 Predictor Rule as an initial athletic eligibility standard. A student-athlete's high school GPA ranking and standard test scores were used to predict a minimum of a 1.6 GPA after the first year of college. Students with a predicted GPA less than 1.6 were deemed ineligible for financial aid and athletics participation (Oriard, 2012). However, the standard was abolished in 1973 as a result of claims that the rule was unfair to minority student-athletes (Gurney et al. 2017; Oriard, 2012). In place of the Predictor Rule was simply a 2.0 high school GPA (Gurney et al., 2017; Ridpath et al., 2007). Later, in
1983, another attempt was made at increasing academic standards when the NCAA adopted Proposition 48. To be eligible, students were required to achieve a minimum combined SAT score of 700 or a 15 on the ACT along with a 2.0 GPA across 11 core high school classes. Again, the standards were challenged on the basis that the required standardized test scores were unfair to minority athletes (Ridpath et al., 2007). In 1992, Proposition 48 was modified by changing the anchor minimum standardized score to a sliding scale but increasing the number of core courses to 13 (Oriard, 2012).

History therefore suggests that while there is definitely merit in the recommendations by Gurney et al., (2015) and Gurney et al. (2017) and Lumpkin et al. (2012) for increased academic standards, such increased standards would also be met with opposition. Furthermore, the history of academic reform has shown that those in opposition to higher standards have prevailed. Thus, one has to wonder if those in power in Division I college athletics (e.g., coaches and athletic directors) would ever approve of academic standards higher than the ones currently in place.

\section{Systemic Changes}

For many years there have been proposed changes to the structures that undergird a student-athlete's academic and athletic life (Gurney et al., 2017; Ridpath 2007, 2010; Simon, 
1985; Schulman \& Bowen, 2001). First, there are concerns over the heavy time commitment that is required in the form of year-round practicing, weight training, meetings, film watching, traveling, and midweek games (Gurney et al., 2017; "National Collegiate," 2016; Simon et al., 2015). Maintaining a schedule as such, severely limits the time needed for academic success, especially when considering the number of athletes that have been granted special admissions. The NCAA limits practicing to 20 hours per week, however, a 2015 NCAA study found that the median number of hours spent on in-season sport related activities for Division I basketball and football players was 34 and 42 hours respectively ("National Collegiate," 2016). Gurney et al., (2017) and Lumpkin et al. (2012) have recommended that athletic time demands be such that they do not interfere with a student-athlete's ability to successfully pursue a college degree. It has also been suggested that seasons be shorted and midweek games be limited (Lumpkin et al., 2012; Shulman \& Bowen, 2001).

Second, virtually all major Division I athletic departments maintain their own academic support staff involving the advising, tutoring and academic eligibility tracking of student-athletes. Because many Division I football and basketball players are academically deficient, the advising process often involves directing student- athletes towards easier courses and majors that the student-athlete did not want to pursue (Gurney et al., 2017; Kelderman, 2018; Ridpath, 2010).
In addition, in order to keep athletes eligible, academic support staff may feel pressure to do academic work for students or give an extraordinary amount of latitude to an athlete that would not be given to a non-athlete student (Gurney et al., 2017; Ridpath, 2010). As a result, it has been suggested that academic support and advising come from university staff outside of athletics or at the very least be supervised and funded via an academic entity, such as a provost or academic dean, outside of the athletic department. This would prevent athletic staff from manipulating studentathlete academic choices in the interest of maintaining their eligibility and reduce opportunities for academic misconduct (Coalition on Intercollegiate Athletics, 2007; Gurney et al., 2017; Kelderman, 2018; Simon, 1985).

In theory, it does, indeed, seem that reducing the amount of time student athletes spend practicing and competing in athletics could increase student-athletes' likelihood for academic success. However, considering the academic deficiencies that many football and basketball players possess when entering into the university (Barker, 2014; Wolverton, 2014), it is dubious as to whether providing extra time for studying would make-up the deficiencies. It also assumes that if given more time to study, that student-athletes would use the extra time for that purpose. Yet, Simons, Van Rheenen, and Covington (1999) found in a study with Division I athletes that the majority of male football and 
basketball players scored high on failure avoidance (and not motivated to succeed) and failure acceptance as well as high on athletic commitment and low academic commitment. Similarly, a study by Gaston-Gayles (2005) showed that male football and basketball players scored the lowest on academic motivation and the highest on athletic motivation. These studies suggest that it cannot be assumed that more time allowed for academics will boost academic success.

A similar problem may exist concerning the changing of academic support staff for student-athletes. On the face of it, academic advising from non-athletic staff, that in theory, will not manipulate the student-athlete's choice of major or courses, would certainly be a positive change. However, the problem would still remain that many football and basketball players are academically underprepared and would thus lack the academic skills to succeed in more difficult majors combined with academic eligibility of athletes being very important to the competitive and fiscal efficacy that high level intercollegiate athletic programs often place as a priority. This reality was found by Adler and Adler (1985) among a group of Division I basketball players. Many of the players entered into college with aspirations of earning a college degree but lost those aspirations once they realized the difficulty of the academic work conflated with the time demands of basketball. Thus, the bulk of effort and priority was put on basketball often at the expense of academics.

\section{Governance}

Gurney et al. (2017) posited that it is unlikely that any serious academic reform will occur under the governance of the NCAA. This is due to the powerful and wealthy FBS member schools that control much of the decision making which is primarily in the interest of revenue rather than the well-being and education of student-athletes. Therefore, it is improbable that any of the proposed changes highlighted to this point will occur under the NCAA. As an alternative, The Drake Group suggests the establishment of a new federally supported college athletics governing organization that would install a new set of guidelines to promote the wellbeing of student-athletes as it relates to their education, health, and safety as well as financial integrity (Lopiano, et al., 2015). Importantly, the maintenance of these guidelines would be governed by a board of directors that are primarily independent from the member institutions of the new proposed organization, i.e., former presidents, athletics directors, faculty members, etc. in order to remove the conflict of interest problem that currently plagues the current NCAA governance structure.

The establishment of a new national governance organization could, indeed, allow for sweeping changes across college athletics. However, it is clear 
that those that profit (coaches, athletic directors, conference commissioners, etc.) are unsupportive of major reform (Gurney et al., 2017; Shulman \& Bowen, 2001). It is also clear that such lack of support has been ongoing, as Weistart (1987) also suggested intervention from Congress to affect the necessary reforms. Thus, it remains to be seen whether or not Congress will intercede.

Weistart (1987) also suggested intervention from Congress to affect the necessary reforms. Notably, Weistart (1987) was calling for federal intervention 30 years ago. Thus, it remains to be seen whether or not Congress will intercede.

\section{Taking "Student" out of the "Student-Athlete"}

The term "student-athlete" is intended to connote a balance of education and athletics ("NCAA Core Values," n.d.). However, what is idealized and what is reality in big-time Division I college athletics is clearly not the same. Consequently, a variety of academic reform efforts and proposals have been made to restore the true meaning of a student-athlete (Gurney et al., 2017; Lopiano, et al., 2015; Ridpath, 2018; Simon, 1985) but such efforts have had little impact. Notably, Gurney et al. (2017) stated, "Insofar as the NCAA is controlled by a small number of the wealthiest (FBS) members, we doubt that NCAA reform is possible" (p. 225). Thus, perhaps a more radical approach is needed to obviate rampant academic misconduct and exploitation of studentathletes.

Some have suggested that if one of the purposes of a university is to be a purveyor of public entertainment then why not allow major Division I football and basketball players to be paid professionals (French, 2004; Guttman, 1988; Simon, 1985). For example, Bill Bradley, former professional basketball player and United States Senator suggested over 30 years ago that major college athletes be paid professionals. Whether or not they pursued a college degree would be their choice (as cited in Simon 1985). Those supporting such a view maintain that the hypocrisy of the student-athlete moniker would finally be abolished (French, 2004). No longer would athletic departments need to help academically unqualified students "major in eligibility." In essence, athletes could simply be athletes, or student-athletes depending on one's comfort level with balancing academics with athletics.

In the interest of ending the studentathlete facade that has been evidenced by a myriad of academic scandals and exploitation of student-athletes, disposing of the student-athlete concept seems to hold merit. However, treating college athletes as paid professionals is problematic. For example, how much should a football or basketball player be paid? In professional sports many players are typically paid more than coaches. Considering that many college coaches hold seven figure salaries, this would 
mean that many college football and basketball players would be paid multimillion dollar salaries (Gurney et al., 2017). This leads to the next question. What would be the revenue sources to provide such salaries? Considering that most university athletic departments operate under a deficit, it is difficult to fathom how athletes could be paid market value (Gurney et al., 2017). In addition, Simon (1985) suggested that paying college athletes would put college athletics on the same level of professional sport. For example, similar to professional sports, college athletes might demand larger salaries or ask to be traded to a different team/university. Ultimately, these types of conditions could taint the original attractiveness of college athletics, e.g., that college athletes are amateurs and students.

In light of the potential complications of paying college athletes, perhaps it is not a viable option and there may be better ways beyond trying to save the current and outdated amateur model without paying the athletes a salary. Consequently, the second part of Bradley's proposal may be worth considering. That is, giving-athletes the option of pursuing a degree while playing football or basketball. Providing this choice would eliminate the need to fraudulently keep academically deficient athletes eligible as well as put education on the time table the athlete chooses rather than a manufactured education geared toward eligibility maintenance and bogus educational attainment. It would also diminish the exploitation that occurs when athletes are misled into believing that they have the opportunity to earn a degree when in reality many athletes do not have the skills to do college level work, have not been remediated effectively, or are simply not motivated to pursue a degree when their athletic peak and value is at its apex (Gurney et al., 2017). On other hand, athletes who have the necessary academic skills to earn a degree could choose to do so without any minimum requirements such as percentage of degree requirements, satisfactory progress, full-time required enrollment or even grade point average. The onus would be on the student and he or she would not be constrained to a five-six year time frame for graduation either as dictated by NCAA rules and graduation rate disclosure policies. In other words, fans, administrators, and coaches should not be fixated on when the educational opportunity happens, just that the opportunity is there and can be realized at the athlete's pace and choice. According to French (2004), such an approach can also be rationalized from the standpoint of universities being providers of entertainment. In essence, because football and basketball players are providing large scale entertainment to millions, they are therefore fulfilling an important aspect of a university's mission which arguably voids the student requirement. Athletes could simply be regarded as entertainers while they make their bid for the professional ranks. 
At this point, it is not known how many Division I football and basketball players would choose not to pursue a degree while playing football or basketball. As mentioned, Adler and Adler (1985) found that most Division I basketball players in their sample initially aspired to earn a college degree. It was not until the players began to experience the difficult realities of doing college level work while also meeting the time demands of basketball that many players relinquished their hopes of obtaining a degree (Adler \& Adler, 1985). However, Adler and Adler's (1985) study was conducted over 30 years ago. Considering the increased amount of money that can now be earned in professional sport as well as the challenges of finding a job in today's competitive market, more athletes may be motivated to turn professional while less may be inspired to earn a degree. As a result, it is important to assess college football and basketball players' interest in focusing on their sport only versus the number of them that would prefer to pursue a degree and play ball. If a large percentage in this study's sample prefers the former, recommendations can be made for the NCAA to institute such a choice. Alternatively, if it is shown that most athletes want to pursue a degree, then an argument can be made that coaches, athletic departments, and other university staff have a responsibility to recruit and admit students who truly can be "student-athletes" and handle the rigors of both.

\section{Method \\ Participants and Procedures}

A total of 153 Division I football (FBS) and basketball players participated in this study by responding to a 6-item electronic questionnaire via SurveyMonkey. The number of respondents varied slightly depending on the question. Specifically, there were $n=92$ football and $n=58$ basketball players with the majority either white $(\mathrm{n}=97)$ or African American $(\mathrm{n}=41)$. There were also $(n=15)$ other non-white races.

Obtaining respondents occurred in two stages. For the first stage, Division I football (FBS) and basketball teams in the top 25 of the Associated Press Poll (during the month of November) were randomly selected to receive an email message with a web link to an electronic questionnaire. In the message it was explained that their participation was anonymous which should alleviate any desire to provide socially desirable answers. Athlete email addresses were accessed by locating team rosters on athletic department websites and then utilizing university student directories to obtain student email addresses. After emailing football players from six FBS teams, the researchers acquired 92 respondents out of 606 total players (15\% response rate). Although the response rate was low, responses to questions were consistently similar. As a result, the researchers ended further data collection for football players. 
Garnering responses from major Division I basketball players was significantly more difficult. Thus, in order to garner more responses, the authors purposely selected smaller Division I basketball universities with the hope of reaching more willing respondents (second stage). A total of 43 (23 were smaller Division I universities) Division I basketball teams were emailed the questionnaire which yielded responses from 58 basketball players out of 596 (10\% response rate). Again, although the response rate was low, a decision was made to close data collection as result of a consistent response pattern similar to football players.

\section{Design}

A non experimental descriptive design was utilized to answer this study's research question. According to Johnson and Christensen (2012), non-experimental descriptive designs are appropriate when the researcher is interested in understanding the attitudes, beliefs, and behaviors of a particular population. In cases as such, the researcher does not seek to study causal relationships, but rather, describing particular characteristics or variable relationships within a population. Thus, this study aimed to explore and describe Division I football and basketball players' attitudes towards the option of playing their sport and earning a degree or playing their sport only.

\section{Data Collection Method}

A 6-item questionnaire was developed to answer the key research question for this study. Specifically, the questionnaire sought information concerning: 1 ) gender, 2) race 3) sport played (basketball or football), 4) the players' choice to only play their sport or play and pursue a degree, 5) if athletes think they can play professionally, and 6) whether or not they would choose to return to school at a later time to pursue their degree (applicable to those that only want to play their sport. In addition, question \#4 asked the respondents to briefly explain their choice of playing only or playing and pursuing a degree.

\section{Data Analysis}

A frequency distribution analysis was conducted to examine responses to key items (questions \#4, \#5, and \#6) on the questionnaire (Table 1). A chisquare test of independence and crosstab analysis were also employed to assess relationships among certain questions. This included analyzing the relationship between whether or not athletes thought they could turn professional and whether or not they would choose to play their sport only or play their sport and earn a degree, and the relationship between race and choosing to play sport only or play sport and pursue a degree.

A content analysis was conducted on the short answer responses to determine any patterns or themes in the athletes' responses. Specifically, when conducting a content analysis, "The analyst looks 
for quotations or observations that go together, that are examples of the same underlying idea, issue, or concept (Patton, 1987, p.149). This is precisely what the authors did in analyzing the responses to the open-ended part of question \#4; the authors categorized similar responses into particular themes.

\section{Results}

\section{Quantitative Analysis}

Frequency distribution analysis. Results from the frequency distribution analysis (Table 1) showed that 126 out of $153(82.3 \%)$ Division I football and basketball players would choose to play their sport and simultaneously earn their degree (question \#4). In contrast, 27 out of $153(17.6 \%)$ football and basketball players would choose to play their sport only. In addition, 90 out of 153 (58.8\%) football and basketball players believe that they can play professionally, 31 out of $153(20.2 \%)$ indicated they cannot, and 32 out of $153(20.9 \%)$ were unsure (question \#5). Lastly, question \#6 asked specifically, those athletes that would prefer to play their sport only, if they would like to return to college at a later time to earn their degree. Unfortunately, responses to question \#6 suggest that many of the respondents did not fully understand the question or read the question carefully. Consequently, this question was removed from the analysis.

Table 1 Frequency Distribution Analysis on Responses to Questionnaire

\begin{tabular}{|l|l|l|l|l|}
\hline Question & Male & & & Total \\
\hline Q1. Gender & $153(100 \%)$ & & & 153 \\
\hline Question & White & Black & Other & Total \\
\hline Q2. Race & $97(63.3 \%)$ & $41(26.7 \%)$ & $15(9.8 \%)$ & 153 \\
\hline Question & Football & Basketball & & Total \\
\hline Q3. Sport & $92(61.3 \%)$ & $58(38.6 \%)$ & & 150 \\
\hline Question & $\begin{array}{l}\text { Play and Earn } \\
\text { Degree }\end{array}$ & Play Only & & $\mathbf{1 5 3}$ \\
$\begin{array}{l}\text { Q4. Play and earn degree/ } \\
\text { play only }\end{array}$ & $126(82.3 \%)$ & $27(17.6 \%)$ & & \\
\hline $\begin{array}{l}\text { Question } \\
\text { Q5. Play professionally }\end{array}$ & $\begin{array}{l}\text { No }(20.2 \%) \\
\text { 3nsure }\end{array}$ & $\begin{array}{l}\text { Yes }(20.9 \%) \\
90(58.8 \%)\end{array}$ & $\begin{array}{l}\text { Total } \\
153\end{array}$ \\
\hline
\end{tabular}

Note: There were three respondents that did not answer question \#3. 
Chi-square and crosstab analysis. Results from the chi-square test of independence $(3 \times 2)$ showed that there was a statistically significant relationship $\mathrm{X}^{2}(2, \mathrm{~N}=153)=12.334, \mathrm{p}<.05$ between an athlete's belief that they can play professionally and their choice to either play and earn their degree or play only. Further, Cramer's V was .284 suggesting a moderate relationship or level of dependence in terms of practical significance. This can be seen in the crosstab analysis in which 60 out of $63(95.2 \%)$ football and basketball players that do not believe they can play professionally or that are "unsure" indicated that they would like to play and pursue a degree (Table 2). Contrariwise, 24 out of $90(26.7 \%)$ athletes that believe they can play professionally would choose to play only compared to 3 out $63(4.7 \%)$ that were either unsure or do not believe they can play professionally would choose to play only (Table 2). In addition, Table 3 shows that 24 out $27(88.9 \%)$ athletes that chose to play only also believe they can they can turn professional. Thus, there does appear to

Table 2 Crosstab Analysis: Earn a Degree While Playing/Play Sport Only by Do You Believe You Can Play Professionally (Column Percentages)?

\begin{tabular}{lcccc}
\hline & \multicolumn{4}{c}{ Do You Believe You Can Play Professionally? } \\
\cline { 2 - 5 } $\begin{array}{l}\text { Degree While } \\
\text { Playing/Play }\end{array}$ & No & Unsure & Yes & Total \\
$\begin{array}{l}\text { Only } \\
\text { Earn Degree }\end{array}$ & $30(96.7 \%)$ & $30(93.8 \%)$ & $66(73.3 \%)$ & 126 \\
$\begin{array}{l}\text { While Playing } \\
\text { Play Only }\end{array}$ & $1(3.2 \%)$ & $2(6.3 \%)$ & $24(26.7 \%)$ & 27 \\
Total & 31 & 32 & 90 & 153 \\
\hline
\end{tabular}

Table 3 Crosstab Analysis: Earn a Degree While Playing/Play Sport Only by Do You Believe You Can Play Professionally (Row Percentages)?

\begin{tabular}{lcccc}
\hline & \multicolumn{4}{c}{ Do You Believe You Can Play Professionally? } \\
\cline { 2 - 5 } $\begin{array}{l}\text { Degree While } \\
\text { Playing/Play }\end{array}$ & No & Unsure & Yes & Total \\
$\begin{array}{l}\text { Only } \\
\text { Earn Degree }\end{array}$ & $30(23.8 \%)$ & $30(23.8 \%)$ & $66(52.3 \%)$ & 126 \\
$\begin{array}{l}\text { While Playing } \\
\text { Play Only }\end{array}$ & $1(3.7 \%)$ & $2(7.4 \%)$ & $24(88.9 \%)$ & 27 \\
Total & 31 & 32 & 90 & 153 \\
\hline
\end{tabular}


be somewhat of a relationship between one's belief in their ability to turn professional and their choice of playing and pursuing a degree or playing only. However, it should also be pointed out that 66 out of $90(73.3 \%)$ football and basketball players that believe they can compete professionally also want to pursue a degree while playing (Table 2). This latter result is likely the reason why there was not a stronger relationship between an athlete's belief that they can play professionally and choosing to play and pursue a degree or play only.

A chi-square test of independence (2x2) and crosstab analysis was also conducted to explore the relationship between race (only the races of black and white were analyzed due to the small $\mathrm{n}$ sizes of other races in the sample) and choosing to play one's sport only or play and pursue a degree. This particular analysis was explored given the statistics that have shown lower graduation rates for black Division I football and basketball players compared to white (Lapchick et al., 2017; Lapchick \& Liang,
2017). Race was also analyzed considering that the majority of professional (National Basketball Association and National Football League) basketball and football players are Black (Lapchick \& Balasundarum, 2017; Lapchick \& Marfatia, 2017). Results from the chisquare analysis showed that there was a statistically significant relationship $\mathrm{X}^{2}$ $(1, \mathrm{~N}=138)=5.727, \mathrm{p}<.05$ between race and whether one would choose to play and pursue a degree or play only. In addition, Cramer's V was .204 suggesting only a small relationship in practice. The relationship or lack thereof can be seen more clearly in the crosstab analysis in which the large majority of both Black $(70.7 \%)$ and White $(87.6 \%)$ football and basketball players would choose to play and pursue a degree (Table 4). However, there were a larger percentage of Black athletes $(29.3 \%)$ that would choose to play sport only compared to white $(12.3 \%)$ which would support the small relationship evidenced by Cramer's V = .204 (Table 4).

Table 4 Crosstab Analysis: Earn a Degree While Playing/Play Sport Only by Race (Column Percentages)

\begin{tabular}{lccc}
\hline & \multicolumn{3}{c}{ Race } \\
\cline { 2 - 4 } $\begin{array}{l}\text { Degree While } \\
\text { Playing/Play Only }\end{array}$ & White & Black & Total \\
Earn Degree While & $85(87.6 \%)$ & $29(70.7 \%)$ & 114 \\
Playing & & & \\
Play Only & $12(12.3 \%)$ & $12(29.3 \%)$ & 24 \\
Total & 97 & 41 & 138 \\
\hline
\end{tabular}




\section{Qualitative Analysis}

A total of 93 out of 153 (60.7\%) football and basketball players provided brief reasons for choosing to play their sport only or play and pursue a degree. A total of 15 themes emerged from the content analysis that was performed on the athletes' various reasons. The number of responses categorized into a particular theme ranged from 3 to 23 responses. There were also 11 responses that the authors felt were too unique to be categorized. For the purposes of this paper the authors elected to present the themes that possess a minimum of 8 responses and which are thus deemed more substantive to this particular study. These five themes include "sport doesn't last forever," "degree/education more important," "backup plan," "time," and "future."

Sport doesn't last forever. This theme possessed 23 different responses which was the largest number of responses for a particular theme. Many of the responses related to this theme were explicit about the brevity of one's football career or sport not lasting "forever." For example, one player said, "Football can be cut short at any time." Another athlete said, "I know my sports career won't last forever so I want to prepare myself academically for the future by earning a degree." Or, as another player maintained, "Sports are not everything, it is something I get to do for fun but won't have forever to provide for me. So I would like to earn my degree above everything."

\section{Degree/education more} important. A total of 17 different responses that formed this theme related to prioritizing education over athletics. The statements were brief but to the point. For example, one player said, "Education is my first priority." Another athlete stated, "Your degree is the most important part of being here." Similarly, one player said, "That's why I chose to go to college." For others, athletics was referenced as a vehicle to obtain a degree. For instance, one athlete stated, "A degree is the goal but the sport is just a platform to get it." A second athlete said, "I want to get an education. Athletics are there to help me pay for this and make it easier to gain."

Backup plan. A total of 11 different responses comprised this theme. Many of the athletes within this theme said they needed a "backup plan" or that they needed a degree to create other options. For example, one athlete said, "I don't want to play football forever and want to have a backup plan." A second athlete said, "Sport is not guaranteed to last forever. I have to plan for my future. Even if it is a backup plan." A third athlete said, "I would choose to earn a degree because then I could be able to get a job after college if football didn't work out."

Time. A total of 10 responses formed this theme related to the issue of athletes saying they do not have enough "time" to play football or basketball and study. Notably, 9 out of the 10 responses were from athletes who said they believe 
they can become a professional athlete. For instance, one athlete said, "Doing school and football [is] too hard and too stressful." Another athlete stated, "Because it's hard to excel at both at the same time." A third athlete said, "It would make it easier to focus on your craft and your degree at separate times." Lastly, a fourth athlete provided a more detailed and illuminating response by stating:

I believe in this statement strongly because as a football player, to be great you have to practice, train, and workout mostly every day and we don't have as much time to put in an A effort towards a class since we don't have much off time compared to a regular student who studies all day and is well prepared for a class. This is why playing a sport only is better for athletes because it will help us focus and better ourselves without worrying about leaving 5:30am workouts then take a nap, then get ready for a 8:am class.

Future. A total of eight different athletes explained their desire to play and earn a degree relating to the importance of their "future." For example, one athlete said, "I think that earning a degree through education is incredibly valuable and useful for my future." A second athlete, stated, "I'm here to get [an] education for my future after basketball". A third athlete said, Realistically, I know that a career in sports is not guaranteed. While I would love to only play sports, I know that I need to better myself in other ways in order to prepare myself for my future.

\section{Discussion}

The aim of this study was to gain an initial understanding of Division I football and basketball players' attitudes towards having the option of playing and pursuing a degree or playing their sport only. This knowledge was sought in the interest of reforming widespread academic misconduct in college athletics. Athletic department staff would no longer need to fraudulently assist athletes with low academic ability or interest. Athletes as such would be able to choose the option of playing only.

An overwhelming majority (82.3\%) of Division I football and basketball players indicated they would choose to play their sport and pursue a degree. This result is consistent with a previous study that found most Division I football and basketball players placed high importance on earning their degree (Center for the Study of Athletics, 1988). In addition, Adler and Adler (1985) examined Division I basketball players' experiences with university academics and athletics participation. Among their findings, they found that most entering freshmen basketball players had aspirations of earning a degree and obtaining a meaningful career. However, by the beginning of their sophomore year, the majority began to see the difficulty of meeting the demands of both academics and athletics and subsequently lost their academic motivation and belief in their 
ability to earn a degree. The current study, however, did not collect information on athletes' year in school. As a result, it is not known how many of those that want to play and pursue a degree are freshmen. It is doubtful that the 126 out of 153 that indicated they would play and pursue a degree are entirely freshman as akin to the findings by Adler and Adler (1985). Instead, it is likely that there are a percentage of athletes that are upper class students and still desire to earn a degree even after being exposed to the demands of college athletics and greater difficulty of higher education.

The findings also revealed that the majority of those who believe they can turn professional also want to play and pursue their degree while in college. This result is consistent with a previous study that found many athletes who aspire to be professional athletes also want to earn their degree (Center for the Study of Athletics, 1988). However, it should also be noted that $26.7 \%$ of athletes in this study's sample who believe they can play professionally would choose to play their sport only. Thus, there is also some evidence to suggest that the belief in one's ability to play professionally may also impact one's desire to play their sport only. Lastly, the results showed that the majority of Black and White players would choose to play and purse their degree. Such a finding is similar to a previous study that found Black and White athletes did not differ in their desire to earn a degree (Sellers, 1992). On the other hand, it is perhaps worth mentioning there were a higher percentage of Black $(29.3 \%)$ compared to White athletes $(12.3 \%)$ that would choose to play only. This latter difference may be somewhat explained by research suggesting that young Black athletes are socialized into believing that their best chance for economic success is to focus on athletics (Coakley, 2009). Similarly Sage and Eitzen (2016) have theorized that Blacks may perceive sport participation to be the primary vehicle for economic success as a result of fewer opportunities for career advancement.

Overall, it is important to consider why most athletes in this study's sample want to pursue their degree while playing compared to those that want to play only. First, it may be that the large majority who want to play and pursue a degree are better students compared to those that want to play only. As evidence, many of the students that would choose to play only also indicated having a lack of time to study and participate in athletics. In contrast, athletes wanting to play and pursue a degree did not mention time being an issue. This could suggest that stronger students know how to manage their time compared to weaker students who may not. It may also suggest that student-athletes who believe they can turn professional and are struggling in school are more inclined to opt for playing their sport only. Second, studies by Simons, Rheenen, and Covington (1999) and Gaston-Gayles (2005) found that Division I revenue college athletes possessed higher levels of 
athletic commitment and lower levels of academic commitment compared to non revenue athletes. Based on these findings, one might expect most Division I football and basketball players to choose the option of playing their sport only. However, the current study found mostly the opposite which could suggest that many of the athletes in this study's sample have a higher level of academic commitment compared to the smaller percentage that would choose to play their sport only.

\section{Conclusions}

The results from our study allow for a couple of tentative conclusions. First, the majority of football and basketball players indicated that they would like to play and pursue their degree even if they believe they can play professionally. This suggests that many Division I football and basketball players beyond the current study may desire to earn their degree, which in turn, requires coaches, the NCAA, and other university administrators to deliver on their promises of athletes receiving an opportunity to play and earn a degree (Gurney et al., 2017). More specifically, given the qualitative findings that demonstrated the athletes' sincerity towards their education, it is incumbent on academic support staff to provide these student-athletes the liberty of choosing a degree that is of interest to them rather than pushing athletes toward easier degree programs (Gurney et al., 2017, Oriard, 2012). It also means that coaches should provide ample time for athletes to study and be academically successful (Gurney et al., 2017; Simon et al., 2015). Lastly, coaches should not recruit athletes that will be unable to succeed academically. Doing so is misleading to athletes who initially believe they can earn a degree (Adler and Adler, 1985).

Second, the present study has shown that there are a percentage of athletes that would prefer to play their sport only and that this percentage could be much larger depending on the attitudes of the non responders. Further, based on the research by Simons et al. (1999) and Gaston-Gayles (2005), this particular segment of athletes (those that want to play only) may have a higher level of commitment to athletics and a much lower commitment to academics as well as weaker academic ability. Thus, playing one's sport only could be a good option for athletes with these characteristics.

Some, however, may question the notion of a college athlete not pursuing a degree while playing football or basketball for a given university. In response, those such as French (2004) have suggested the need to consider a university more broadly. Rather than conceptualizing universities strictly as places for teaching and scholarship, French has argued that many universities and athletic departments include the purveyance of service and entertainment within their mission statements. According to French, this, then, allows for the legitimization of 
considering athletics as entertainment and athletes as entertainers. Applied to our recommendation to allow football and basketball players to play their sport only, athletes as such could be considered entertainers who provide a service to the community at large. This would also then eliminate the façade of "studentathletics" at the big-time Division I level.

\section{Limitations and Future Research}

The current study requires acknowledgement of its limitations as well as directions for future research. First, there were a high number of non responders which prevents us from gaining a clearer understanding of Division I football and basketball players' attitudes towards having the choice of playing and pursuing a degree or playing their sport only. A follow-up study with a larger sample of Division I football and basketball players is needed to determine more definitively how many athletes would prefer the option of playing their sport only.

Second, given that this study was an initial exploration into Division I football and basketball players' attitudes towards playing and pursuing a degree or playing one's sport only, certain data was not collected that could be utilized for additional studies. This data includes information such as year in school, grade point average, socioeconomic background, and academic and athletic motivation. In addition, it is not known more specifically why some athletes from the present study feel there is not enough time for both athletics and school whereas the larger majority said nothing about time being a problem, while also showing a much stronger interest in earning their degree. Towards this end, qualitative studies with Division I football and basketball players could be conducted to obtain a deeper understanding of how athletes view academics versus athletics and how it might impact their choice to play and pursue a degree or play their sport only. Qualitative studies could help uncover important environmental variables that may play a powerful role in an athlete's commitment to academics or a lack thereof.

\section{References}

About the Knight Commission (n.d.). Retrieved from https://www. knightcommission.org/about-knightcommission/

Adler, P., \& Adler, P. A. (1985). From idealism to pragmatic detachment: The academic performance of college athletes. Sociology of Education, 58, 241250.

Axe, B. (2015, January 21). Report: NCAA investigating 20 schools for academic fraud. Syracuse.com. Retrieved from http://www.syracuse.com/ axeman/index.ssf/2015/01/report_ ncaa_investigating_20_schools_for_ academic_fraud.html

Barker, J. (2012, December 22). 'Special admissions' bring colleges top athletes, educational challenges. The Baltimore Sun. Retrieved from http:// articles.baltimoresun.com/2012-12- 
22/sports/bs-sp-acc-sports-specialadmits-20121222_1_athletes-specialadmissions-special-admits

Center for the Study of Athletics. (1988). Report No. 1: Summary results from the 1987-1988 national study of intercollegiate athletes. Palo Alto, CA: American Institutes for Research.

Coakley, J. (2009). Sports in society $\left(10^{\text {th }}\right.$ ed.). Boston, MA: McGraw-Hill.

Coalition on Intercollegiate Athletics (2007). Framing the future: Reforming intercollegiate athletics. http:/ / www.thecoia.org/wp-content/ uploads/2014/07/Framing-theFuture-Proposals-2007-1.pdf

Davies, R. O. (2007). Sports in American life: A bistory. Malden, MA: Blackwell Publishing.

Edelman, M. (2017). From studentathletes to employee-athletes: Why pay for play model of college sports would not necessarily make educational scholarships taxable. Boston College Law Review 58(4), 1137-1168.

French, P. (2004). Ethics and college sports: Ethics, sports, and the university. Lanham, MD: Rowman \& Littlefield Publishers, Inc.

Gaston-Gayles, J. L. (2005). The factor structure and reliability of the student athletes' motivation toward sports and academics questionnaire. Journal of College Student Development, 46(3), 317327. Doi: 10. 1353/csd.2005.0025 Gurney, G., Lopiano, E., Snyder, D., Willingham, M., Meyer, J., Porto, B.,.. Zimbalist, A. (2015). The Drake Group position statement: $W$ by the NCAA Academic Progress Rate (APR) and
Graduation Success Rate (GSR) should be abandoned and replaced with more effective academic metrics. Retrieved from http:// thedrakegroup.org

Gurney, G., Lopiano, D. A., Zimbalist, A. (2017). Unwinding madness: What went wrong with college sports and how to fix it. Washington, D. C.: Brookings Institution Press.

Guttman, A. (1988). The anomaly of intercollegiate athletics. In J. Andre \& D. N., James (Eds.), Rethinking college athletics (pp. 17-30). Philadelphia, PA: Temple University Press.

James, E. (2016, July 7). Former Georgia Southern staff members provided impermissible academic assistance. NCAA.org. Retrieved from http:// www.ncaa.org/about/resources/ media-center/news/former-georgiasouthern-staff-members-providedimpermissible-academic-assistance Johnson, B., \& Christensen, L. (2012). Educational research: Quantitative, qualitative, and mixed approaches (4th ed.). Thousand Oaks, CA: Sage Publications.

Kelderman, E. (2018, January 28). Who should oversee athletes' academic progress? The Chronicle of Higher Education. Retrieved from https:// www.chronicle.com/article/WhoShould-Oversee-Athletes-/242351 Lapchick, R., \& Balasundarum, B. (2017). The 2017 Racial and gender report card: National Basketball Association. Retrieved from the University of Central Florida, The Institute for Diversity and Ethics in Sport website: http://nebula.wsimg. 